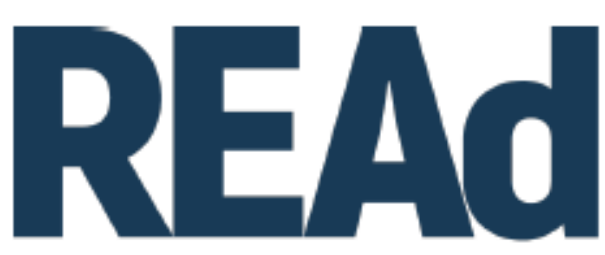

Revista Eletrônica de Administração

\title{
INFLUENCE FACTORS OF CULTURE OF INTELLIGENCE IN ORGANIZATIONS ${ }^{1}$
}

\author{
Vivian Aguiar de Souza ${ }^{2}$ \\ Raquel Janissek-Muniz ${ }^{3}$
}

http://dx.doi.org/10.1590/1413-2311.325.107447

\begin{abstract}
RESUMO
Organizations have recognized intelligence processes to deal with uncertainties, anticipate and better direct their decisions, aiming at greater competitiveness and sustainability. Among the influencing factors in these processes, culture, built by values, standards and behaviors, is strongly highlighted. In order to identify which characteristics are present in the culture of intelligence, we explore different elements covered in the literature. Studies point to cultural factors of leadership, communication, trust and collaboration, learning, and an orientation to the future and innovation as capable of influencing the intelligence processes. Aiming to identify factors of organizational culture that can influence intelligence processes in organizations, a SLR was carried out to form the construct "intelligence culture", with validation by specialists, via Card Sorting and Delphi method. As a result, factors as leadership, appropriate communication and team awareness were identified. In terms of theoretical contribution, this study identifies the organizational culture factors which can influence the intelligence processes, uniting findings from the literature and the intelligence specialists' opinions. It also proposes an instrument that can serve as a reference for future studies of culture factors and intelligence in organizations. In practical terms, organizations can diagnose and think strategies that develop the organizational culture in their processes.
\end{abstract}

Keywords: Organizational Culture. Intelligence Culture. Intelligence Processes. Intelligence.

\footnotetext{
${ }^{1}$ Recebido em 11/9/2020, aceito 30/6/2021.

${ }^{2}$ Universidade Federal do Rio Grande do Sul - Programa de Pós-Graduação em Administração; Porto Alegre RS (Brasil); http://orcid.org/0000-0001-5844-8113; vivian.aguiar.souza.adm@ gmail.com.

${ }^{3}$ Universidade Federal do Rio Grande do Sul - Programa de Pós-Graduação em Administração; Porto Alegre RS (Brasil); https://orcid.org/0000-0002-0657-6559; rjmuniz@ufrgs.br.
} 


\title{
FATORES INFLUENCIADORES DE CULTURA DE INTELIGÊNCIA NAS ORGANIZAÇÕES
}

\begin{abstract}
Organizações têm reconhecido processos de inteligência para lidar com incertezas, antecipar e melhor encaminhar suas decisões, visando maior competitividade e sustentabilidade. Dentre os fatores influenciadores no êxito desses processos, a cultura, construída por valores, padrões e comportamentos, é fortemente apontada. Para identificar quais características são apresentadas na cultura de inteligência, exploramos diferentes elementos apontados na literatura. Estudos apontam fatores culturais como liderança, comunicação, confiança e colaboração, aprendizado e orientação para o futuro e inovação como capazes de influenciar os processos de inteligência. Com o objetivo de identificar fatores da cultura organizacional que podem influenciar os processos de inteligência nas organizações, foi realizada uma RSL para formar o construto "cultura de inteligência", com validação por especialistas, via Card Sorting e método Delphi. Como resultado, fatores tais como liderança, comunicação apropriada, e consciência da equipe foram identificados. Em termos de contribuição teórica, o trabalho identifica fatores da cultura organizacional que podem influenciar os processos de inteligência, unindo achados da literatura e opiniões de especialistas em inteligência. Propõe igualmente um instrumento que pode servir de referência para estudos futuros de inteligência e cultura nas organizações. Em termos práticos, as organizações podem diagnosticar e pensar estratégias que desenvolvam a cultura organizacional em seus processos.
\end{abstract}

Palavras-chave: Cultura Organizacional. Cultura de Inteligência. Processos de Inteligência. Inteligência.

\section{FACTORES INFLUYENTES DE CULTURA DE INTELIGENCIA EN LAS ORGANIZACIONES}

Organizaciones cuentan con procesos de inteligencia reconocidos para hacer frente a incertidumbres, anticipar y orientar mejor sus decisiones, apuntando a una mayor competitividad y sostenibilidad. Entre los factores que influyen en estos procesos, se destaca fuertemente la cultura, construida por valores, estándares y comportamientos. Para identificar qué características están presentes en la cultura de la inteligencia, exploramos diferentes elementos cubiertos en la literatura. Los estudios apuntan a factores culturales de liderazgo, comunicación, confianza y colaboración, aprendizaje y orientación hacia el futuro y la innovación como capaces de influir en los procesos de inteligencia. Con el objetivo de identificar factores de la cultura organizacional que pueden influir en los procesos de inteligencia en las organizaciones, se realizó una RSL para conformar el constructo "cultura de la inteligencia", con validación por especialistas, vía Card Sorting y método Delphi. Como resultado, se identificaron factores como liderazgo, comunicación adecuada y conciencia del equipo. En términos de aporte teórico, este estudio identifica los factores de la cultura organizacional que pueden influir en los procesos de inteligencia, uniendo los hallazgos de la literatura y las opiniones de los especialistas en inteligencia. También propone un instrumento que puede servir de referencia para futuros estudios de factores culturales e inteligencia en las organizaciones. En términos prácticos, las organizaciones pueden diagnosticar y pensar estrategias que desarrollen la cultura organizacional en sus procesos. 
Palabras clave: Cultura Organizacional. Cultura de la Inteligencia. Procesos de Inteligencia. Inteligencia.

\section{INTRODUCTION}

Intelligence activities have been growing in terms of business practice (CALOF, 2017). By betting on intelligence processes to monitor their environment (LESCA, 2003), companies aim to obtain information to support their competitive positioning (SEWDASS; DU TOIT, 2014), looking for differential development paths (ROHRBECK; GEMUNDEN, 2011). To carry out intelligence, the organization must have capacity to collect, analyze and use information related to changes in its environment (CARON-FASAN; JANISSEK-MUNIZ, 2004; VIDIGAL, 2013), aiming to protect the organization against threats, seize opportunities and incorporate information into decision-making (SALGUERO; RESENDE JR.; FERNÁNDEZ, 2017).

Despite the recognition of the need for formalized intelligence processes, studies indicate that many organizations do not apply them properly (SEWDASS, DU TOIT, 2015; CAINELLI, 2018), or have difficulties in its implementation (ROHRBECK, KUM, 2018). Duss (2016) and Garcia-Alsina, et al. (2016) believe that one of the reasons is the misalignment with the organizational culture. In 1994, Muller already emphasized the need for behavioral studies on the activities of intelligence, which would bring benefits to the conduct of a culture of intelligence in organizations. Sarker and Sarker (2009), in turn, emphasize the need for a culture to contribute to the development of intelligence processes.

An organizational culture, with people sensitized to voluntarily participate in such processes (LESCA, 2003), motivates employees to engage and enhances a sustainable competitive position (AREFIN; HOQUE; BAO, 2015). Employees are a key part of these processes and must be prepared for them (VISHNEVSKIY; KARASEV; MEISSNER, 2015). Therefore, a culture focused on intelligence needs to involve a team aware of the effectiveness of its practices, promoting communication, collaboration and commitment (HAMMOUD; NASH, 2014). Recognizing the cultural factor as an enabling element of information attention, creating meaning with value sharing and organizational learning, with support from top management (LESCA, 2003), the information flow is strengthened (LEE; TRIM, 2008; NASRI, 2011), encouraging communication and generating results (CEKULS, 2015b).

The intelligence application requires cultural alignment (DUUS, 2016), supporting processes related to the organization values (CEKULS, 2015b). Shared values and beliefs 
define culture and can leverage the success or failure of processes (ROBBINS; JUDGE, 2012). In intelligence processes, the cultural factor is one of the main causes of success, or failure, and without a change in habits, the difficulty in establishing intelligence processes may increase (KLAKURKA; IRWIN, 2016; JANISSEK-MUNIZ, 2016). A favorable organizational culture encourages the monitoring of the environment, promoting engagement in the use of information and communication technologies as key mechanisms for its implementation (MELATI; JANISSEK-MUNIZ, 2017). Intelligence processes experienced by the culture of sharing, collaboration and learning, reinforce the perception of changes, enabling better performance and early response to the environment volatility (MARQUES; VIDIGAL, 2018).

The attempt to expand research related to the culture of intelligence contributes to the expansion of the debate on the factors that precede the implementation of these processes. The intelligence process is recognized as a process conducted by people (FULD, 1995; NASRI, 2011; LESCA; JANISSEK-MUNIZ, 2015; SINGH; TANWAR, 2019), and therefore directly associated with culture. Besides the formal structure (NASRI, 2011), other factors are necessary, related to human involvement, informational and technological resources (FULD, 1995; CAINELLI, 2018). In fact, even organizations with structured processes still suffer from a lack of maturity (PASSINI; JANISSEK-MUNIZ; CAINELLI, 2018), limiting their ability to adapt to the environment (ROHRBECK, KUM, 2018).

Culture has been considered critical in intelligence practices, and its recognition favors awareness of environmental uncertainties and prepares the organization for the future (WIENER, 2018). Arefin, Hoque and Bao (2015) suggest that, in organizations with a favorable organizational culture, the ability of members to manage information is improved. For Whaitaka (2016), a culture focused on raising awareness of the importance of intelligence processes, with the support of top management, strongly contributes to the success of these processes. Thus, and aiming to broaden the understanding of the culture of intelligence, this research aims to identify factors of the organizational culture that can influence the processes of intelligence in organizations. The seek is, besides the understanding of culture for intelligence processes, to enrich the theoretical assumptions about intelligence, expanding knowledge horizons for its effective adoption. It presents itself as an opportunity to advance studies on strategies and actions that identify and appropriate the important cultural characteristics in these processes. In this line, section 2 presents the literature on the culture of intelligence in organizations; section 3 presents the methodological procedures, followed by the research results, and conclusions with limitations and suggestions for future studies. 


\section{THE CULTURE OF INTELLIGENCE IN ORGANIZATIONS}

In dynamic environments, monitoring allows the company to anticipate threats and opportunities, favoring analysis to identify future scenarios, generating learning, providing competitive advantage (SEWDASS; DU TOIT, 2014) and improving organizational performance (VECCHIATO, 2015). In order to identify characteristics and factors that determine a culture of intelligence, a Literature Review was carried out, with searches for the expressions: Culture + "Competitive Intelligence; Strategic Intelligence; Market/Marketing Intelligence; Environmental Scanning; Strategic Scanning; Strategic or Corporate Foresight; Scenario Planning", in the Web of Science, ScienceDirect and Emerald databases, period 20002020 (until June), areas of information, administration and business. Of the 100 articles found, 42 contained elements of organizational culture and intelligence.

The management literature uses several terminologies for intelligence: Competitive, Strategic, Anticipative, Collective, Organizational, etc. with different approaches (BORGES; JANISSEK-MUNIZ, 2017). For Rios et al. (2011, p.62), "there are recognized differences in understanding between the focus of attention of these different nomenclatures, creating difficulties in the academy and even in the business environment for those who seek them as support in the search for information and identification of innovations". The diversity of terms makes it difficult to elaborate a comprehensive approach to intelligence in companies (VISHNEVSKIY; KARASEV; MEISSNER, 2015). The main differences point to applicability, framework, environment and objectives (JANISSEK-MUNIZ, 2016). Regardless of the focus, Rios and Janissek-Muniz (2014) identify that all types of intelligence are concerned with providing useful information for decision making, generating insights that can be used to define strategy, creating opportunities or preventing business vulnerabilities.

For Fuld (1995), an intelligence system must be based on organizational culture and is essentially a human issue. Warrick, Milliman and Ferguson (2016) claim that the organizational culture represents the "accumulated learning" that allows the organization to adapt to its environment. For Sewdass and Du Toit (2014), employees must recognize the importance of intelligence processes and must be trained to acquire knowledge to generate opportunities. Thus, understanding the role of organizational culture in the intelligence process is crucial, allowing understanding values, beliefs and behaviors that enhance process improvements.

\subsection{ORGANIZATIONAL CULTURE \& CULTURE OF INTELLIGENCE}

The organizational culture is responsible for constraining, stabilizing, and providing structure and meaning to the group members (SCHEIN, 2004), forming social standards (CEKULS, 
2015b), capable of influencing significantly the attitudes and behaviors of organization members (ROBBINS; JUDGE, 2012). Chér (2016) defines it as the expression of the organization through values, purpose, mission and vision, manifested by behaviors, symbols and systems. Gasparetto (2017) treats organizational culture as a system of values, beliefs and policies, shared and directed by its leaders, constituting the way people act, how the organization conducts its business and relates to stakeholders, how it makes decisions and the level of employee loyalty. Over time, the organization develops shared beliefs about the nature of the business and essential capabilities, forming criteria for judgments (CHOO, 2001).

At the same time that a strong culture provides stability, with shared values (AREFIN: HOQUE; BAO, 2015), it can also configure a barrier (ROBBINS; JUDGE, 2012). In this line, Cekuls (2015b) emphasizes that an organizational culture only supports changes when they correspond to the predominant values of the organization. The type of culture determines the value of information, its sharing and capitalization in business (DAVENPORT, 1998).

Looking at the environment, through intelligence processes, requires the involvement of top management and other areas of the company (LESCA, 2003), requiring cultural change of employees for the success of activities (NASRI, 2011). Factors such as culture and management support are fundamental and can constitute barriers (LESCA; CARON-FASAN, 2008; JANISSEK-MUNIZ, 2016). For Wright, Pickton and Callow (2002), a successful intelligence process has good management style, culture and structure that encourage trust, facilitating the flow of communication and encouraging information.

A culture of intelligence involves explicit and implicit attitudes in organizations and behaviors that influence social perceptions (CHIRU, 2016). Even a defined process (planning, collection, analysis, action) has its success affected by contextual influences, and the culture is determinant (SAAYMAN et al., 2008). For Nelke and Hakansson (2015), organizations need a corporate culture with processes that pre-establish the mentality of looking at the external environment, and not just for themselves, in order to find information and generate knowledge, supporting the intelligence processes. Such values can cause behaviors that result either in the success or failure of the process, as organizations with hostile cultures tend to develop barriers to their implementation (LESCA; CARON-FASAN, 2008; LESCA et al., 2015).

For Melati and Janissek-Muniz (2017), the culture of intelligence is characterized as a standard of shared conduct, with structuring, dissemination and perpetuation of intelligence processes. The collection of information must be based on the commitment of each member, where the incentives for ones' creation and formation of informal networks show an intelligence culture (XU; KAYE, 2007). Some cultural attitudes compromise success in intelligence 
projects: lack of cooperation among members (JANISSEK-MUNIZ, 2016; JAHARUDDIN; MANSOR; YAAKOB, 2016b), resistance to monitoring, difficulties in storing, updating and sharing data, uncertainty aversion, absence of shared interest and team preparation, lack of commitment, engagement and collective spirit, lack of understanding of intelligence usefulness (JANISSEK-MUNIZ, 2016); lack of ethical practices of intelligence, lack of top management support, lack of team training, lack of awareness of the intelligence importance (JAHARUDDIN; MANSOR; YAAKOB, 2016b). Specific efforts must be conducted to strengthen the intelligence culture, seeking its use in the search for sustainability (AGHA; ATWA; KIWAN, 2014). Intelligence is a critical success factor to a sustainable and competitive position, requiring institutional commitment mechanisms (CAPATINA; BLEOJU, 2012) that requires organizational culture and enabling factors (NEMETH, DEW, AUGIER, 2018).

\subsection{INFLUENCE FACTORS OF CULTURE OF INTELLIGENCE}

Vidigal (2013), Sewdass and Du Toit (2014), and Helm, Krinner and Schmalfuss (2014) highlight the importance of the development of culture for the good progress of intelligence processes, under penalty of this constituting a barrier to their development (LESCA; CARONFASAN, 2008). In this sense, factors that influence culture must be identified, at the risk of obstructing the efficient implementation of intelligence processes (CEKULS, 2015b). From the literature investigated, cultural factors influencing intelligence were identified:

\#Culture of Leadership: Mason (2003), Trim and Lee (2006) and Cekuls (2015b) cite the culture led by the leader as crucial in the conduct of intelligence processes. Some authors suggest that these leaders must be senior managers (LESCA, 2003; KANWAL; SINGH; SAMALIA, 2017). Currey, Somogy and Ariyawardana (2016) highlight that the orientation of culture by top management is fundamental and is based on two basic values: (1) recognition of the importance of intelligence and (2) trust in employees in delegating responsibilities for decision making. According to the authors, the top management team is also responsible for conducting culture-changing behaviors, according to their beliefs.

\#Culture of Trust, Cooperation and Collaboration: The association of these terms is due to the similarity between the concepts. According to the Aurélio Dictionary, "cooperação", the portuguese word for cooperation, comes from "assisting, helping; collaborate". In turn, collaboration has its meaning associated with the terms "cooperate" and "contribute". For Capatina et al. (2016), a collaborative culture allows us to conduct intelligence processes. Cekuls (2015a) mentions trust, cooperation, usefulness and availability for teamwork, trust 
being one of the basic pillars in intelligence processes and the key to the information exchange. Trust makes it possible for organizational objectives to be articulated and accepted (CEKULS, 2015b), and for managers to trust shared information. Collaboration depends on mutual trust and respect, creating a culture of support (MEUNIER-FITZHUGH; PIERCY, 2010). The culture of cooperation encourages the dissemination of results (HATTULA et al., 2015), and must be combined with team spirit (KANWAL; SINGH; SAMALIA, 2017). Trim and Lee (2006) talk in "partnership culture", based on trust, with the performance of leaders, with values derived from the best characteristics. Harmonious working relationships and information exchange with openness to change are the result of a partnership culture (TRIM; LEE, 2006). Asghari et al. (2019) point out the collaborative relationship between employees as one of the important sub-indicators of organizational culture for the success of the intelligence process.

\#Culture of Communication: Encourages sharing, leveraging organizational learning (LIM; KLOB AS, 2000). A culture of valuing dialogues, awareness of organizational situations, under the guidance of senior managers, is decisive in strategic definitions in intelligence teams (BURT; HEIJDEN, 2003). Hattula et al. (2015) use the expression "communication behavior" as a function of culture, essential in the dissemination of intelligence between teams. The intelligence culture is also approached as a culture of encouragement and valorization of team communication, throughout the intelligence process (HAMMOUD; NASH, 2014). Capatina and Bleoju (2012) cite communication as a vital tool in sharing knowledge and learning.

\#Culture of Information and Knowledge: For Russo (2010), data is a set of letters, numbers or digits, which taken in isolation does not transmit knowledge, that is, it does not contain a clear reference. Information is all useful data, treated, with significant value, attributed or added to a natural and logical sense for those who use this information (RUSSO, 2010). Finally, knowledge is the information processed by the nodes. Information culture is defined by Davenport (1998) as the standard of behaviors and attitudes of an organization's informational orientation. Russo (2010) emphasizes the culture focused on data, information and knowledge. Lee and Trim (2008), Hattula et al. (2015), and Almeida, Lesca and Canton (2016) note the importance of a culture of stimulating information. Duan, Cao and Edwards (2018) address the issue of data-oriented culture, while Garcia-Alsina, Ortoll and CobarsíMorales (2013) bring the term informational culture. Casartelli et al. (2010) address the culture of Information management, and Viviers, Saayman and Muller (2005) portray the culture of knowledge among teams. For Capatina and Bleoju (2012), the organization must generate intelligence based on knowledge sharing. Cekuls (2015a) addresses the culture of knowledge management, where the exchange of information guarantees access to knowledge by members 
of the organization. Esteban-Navarro and Garcia-Madurga (2019) consider the domain of informational culture of the company as important to the implementation of intelligence, which considers essential to obtain the results of an intelligence process before making or executing a decision.

\#Culture of Intelligence Awareness: This culture is related to the issue of awareness and valuation of intelligence. Viviers, Saayman and Muller (2005), also cited by Asghari et al. (2019), define a culture of intelligence as one whose importance is recognized by all. Jaharuddin, Mansor and Yaakob (2016a) treat the culture of intelligence as one that values the ethical and legal practices of intelligence, being associated with the encouragement and encouragement of sharing among members of the organization. This factor includes the culture of agility, which addresses the awareness that intelligence brings rapid responses to market changes (KANWAL; SINGH; SAMALIA, 2017). Sewdass and Du Toit (2014) suggest that organizations develop a culture of intelligence through awareness.

\#Culture of Learning and Training: For Murray and Carter (2005), a culture of learning supports organizational intelligence, promoting transformation. Capatina and Bleoju (2012), Kononiuk and Sacio-Szymanska (2016) talk about a culture of continuous learning. For Chermack and Nimon (2013), organizational culture is based on individuals capable of perceiving their organizations and then making the behavioral changes for sustained change, based on learning, communication and dialogue. Teams with cultures open to change are more susceptible to adapting to environment changes, facilitating their monitoring (KORTE; CHERMACK, 2007). Sewdass and Du Toit (2014) indicate that organizations develop an intelligence culture with awareness and training for employees, so that they are engaged with top management groups. Araújo, Costa and Aparício (2017) bring continuous training as the basis of culture, driving positive changes for the success of intelligence processes. Asghari et al. (2019) point to organizational learning as a sub-indicator of organizational culture that must be in the implementation of the intelligence process, along with the collaborative relationship.

\#Culture Oriented to the Future and Innovation: The characteristics portrayed here refer to those discussed by Lesca (2003), with its anticipative look at intelligence, under the approach of weak signals. For Lesca and Lesca (2011), it is common for executives to neglect anticipation and ignore warning signs, which can bring catastrophic consequences in their decisions if not interpreted as changes still in formation. The expression of future-oriented culture indicates that the manager leads the organization to a culture of vision of future scenarios by monitoring the external environment (BURT; HEIJDEN, 2003), enhancing awareness of future uncertainties and preparing the organization (VISHNEVSKIY; 
KARASEV; MEISSNER, 2015). Mason (2003) uses the term "culture directed to planning" referring to characteristics that fit as "orientation for the future". For the author, monitoring processes are common in organizations that want to see the change "in advance". Vishnevskiy, Karasev and Meissner (2015) state that the culture of innovation is a precondition for the effective and efficient use of environmental monitoring activities, and consequent orientation for the future. In this sense, the culture of innovation is associated with a future-oriented culture. Managers can focus on innovative organizational culture, informational policies, efficient procedures and formal structure to improve the intelligence of any organization (KANWAL; SINGH; SAMALIA, 2017).

\section{METHOD}

The qualitative exploratory study began with literature review to define the culture of intelligence construct. After identifying seven cultural factors, they were verified through online card sorting (NAHM et al., 2002), according Faria (2010), due to practicality, economy and security. The Usabilitest tool was applied to 11 intelligence professionals (Table 1).

Table 1 - Card Sorting: Results

\begin{tabular}{|c|c|c|c|}
\hline $\begin{array}{l}\text { Acro } \\
\text { nym }\end{array}$ & $\begin{array}{l}\text { Cultural } \\
\text { Factors }\end{array}$ & General Features & Authors \\
\hline $\begin{array}{l}\mathbf{C} \\
\mathbf{L}\end{array}$ & $\begin{array}{l}\text { Culture of } \\
\text { Leadership }\end{array}$ & $\begin{array}{l}\text { Conduction of the organizational culture } \\
\text { by leaders or senior managers. }\end{array}$ & $\begin{array}{l}\text { Mason (2003); Trim and Lee (2006); Cekuls } \\
\text { (2015b); Hattula et al. }(2015) \text {; Currey et al. } \\
\text { (2016); Kanwal et al. }(2017) \text {. }\end{array}$ \\
\hline $\begin{array}{l}\mathbf{C} \\
\mathbf{T} \\
\mathbf{C}\end{array}$ & $\begin{array}{l}\text { Culture, } \\
\text { Trust and } \\
\text { Collaborati } \\
\quad \text { on }\end{array}$ & $\begin{array}{l}\text { Culture with values of trust, cooperation, } \\
\text { usefulness and availability for teamwork. } \\
\text { Mutual trust and respect create a culture } \\
\text { of collaboration and support. }\end{array}$ & $\begin{array}{l}\text { Trim and Lee (2006); Meunier-Fitzhugh and } \\
\text { Piercy (2010); Capatina and Bleoju (2012); } \\
\text { Hattula et al. (2015); Cekuls (2015a, b); } \\
\text { Capatina } \text { et al. (2016); Kanwal et al. (2017); } \\
\text { Asghari et al. (2019). }\end{array}$ \\
\hline $\begin{array}{l}\mathbf{C} \\
\mathbf{C}\end{array}$ & $\begin{array}{l}\text { Culture of } \\
\text { Communica } \\
\text { tion }\end{array}$ & $\begin{array}{l}\text { Culture of encouragement and } \\
\text { appreciation of team communication, with } \\
\text { open dialogues and information sharing. }\end{array}$ & $\begin{array}{l}\text { Lim and Klobas (2000); Burt and Heijden } \\
\text { (2003); Capatina and Bleoju (2012), Hammoud } \\
\text { and Nash (2014); Hattula et al. (2015). }\end{array}$ \\
\hline $\begin{array}{l}\mathbf{C} \\
\mathbf{I} \\
\mathbf{K}\end{array}$ & $\begin{array}{l}\text { Culture of } \\
\text { Information } \\
\text { and } \\
\text { Knowledge }\end{array}$ & $\begin{array}{l}\text { Culture of encouraging the } \\
\text { dissemination/sharing of information and } \\
\text { knowledge between teams. Data-driven } \\
\text { culture. Informational culture. } \\
\text { Information management culture. }\end{array}$ & $\begin{array}{l}\text { Lee and Trim (2008); Jaharuddin et al. (2016b); } \\
\text { Almeida et al. (2016); Duan et al. (2018); } \\
\text { Garcia-Alsina et al. (2013); Casartelli et al. } \\
\text { (2010); Viviers et al. (2005); Pellissier and } \\
\text { Kruger (2011); Esteban-Navarro and Garcia- } \\
\text { Madurga (2019); Lies (2019); Asghari et al. } \\
\text { (2019). }\end{array}$ \\
\hline $\begin{array}{l}\mathbf{C} \\
\mathbf{L} \\
\mathbf{T}\end{array}$ & $\begin{array}{l}\text { Culture of } \\
\text { Learning } \\
\text { and } \\
\text { Training }\end{array}$ & $\begin{array}{l}\text { Culture that supports organizational } \\
\text { intelligence, promoting transformation. It } \\
\text { involves the ability to learn. Culture } \\
\text { focused on the stimulation of intelligence } \\
\text { through training, seeking experience and } \\
\text { engagement }\end{array}$ & $\begin{array}{l}\text { Murray and Carter (2005); Korte and Chermack } \\
\text { (2007); Capatina and Bleoju (2012); Chermack } \\
\text { and Nimon (2013); Kononiuk and Sacio- } \\
\text { Szymanska (2016); Sewdass and Du Toit } \\
\text { (2014); Araújo, Costa and Aparício (2017), } \\
\text { Asghari et al. (2019). }\end{array}$ \\
\hline
\end{tabular}




\begin{tabular}{|c|c|c|c|}
\hline $\begin{array}{l}\mathbf{C} \\
\mathbf{o I} \\
\mathbf{A}\end{array}$ & $\begin{array}{l}\text { Culture of } \\
\text { Intelligence } \\
\text { Awareness }\end{array}$ & $\begin{array}{l}\text { Culture of recognition of the importance } \\
\text { of intelligence. It also covers the culture } \\
\text { of agility, which values quick responses } \\
\text { to changes in the environment. }\end{array}$ & $\begin{array}{l}\text { Viviers, Saayman and Muller (2005); } \\
\text { Jaharuddin, Mansor and Yakoob (2016b); } \\
\text { Kanwal, Singh and Samalia (2017), Asghari et } \\
\text { al. (2019). }\end{array}$ \\
\hline $\begin{array}{l}\text { C } \\
\text { O } \\
\text { FI }\end{array}$ & $\begin{array}{l}\text { Culture } \\
\text { Oriented to } \\
\text { the Future } \\
\text { and } \\
\text { Innovation }\end{array}$ & $\begin{array}{l}\text { Culture of building future scenarios, with } \\
\text { ample visualization of the external } \\
\text { environment and enhancement of warning } \\
\text { signs. It includes a culture of innovation, } \\
\text { valuing new ideas for decision making. }\end{array}$ & $\begin{array}{l}\text { Mason (2003); Lesca (2003); Burt and Heijden } \\
\text { (2003); Vishnevskiy, Karasev and Meissner } \\
\text { (2015); Kanwal, Singh and Samalia (2017). }\end{array}$ \\
\hline
\end{tabular}

Source: Research Data

After card sorting results, the Delphi method was applied to a group of specialists, seeking convergence (KOBUS; WESTNER, 2016). Conventional Delphi was used, which seeks a group opinion on a given subject (MARQUES; FREITAS, 2018). To define the respondents, experience in intelligence was considered (HSU; SANDFORD, 2007), with anonymous identities for non-influence of opinion among members (ROZADOS, 2015). 318 professionals were identified via Linkedin, and questionnaires were sent by email. The 54 respondents from the $1^{\text {st }}$ round received the questions from the $2^{\text {nd }}$ round, so at the end, there were 27 participants. Delphi followed a sequence of two rounds, with adjustment of the questionnaire from the analysis of the $1^{\text {st }}$ round, available from November 30, 2018 to January 7, 2019, obtaining a satisfactory level of consensus (HSU; SANDFORD, 2007). The platform used was Web-KwikSurvey, in an instrument formed by 31 statements with sub-constructs of organizational culture focused on intelligence, providing opinion interspersed with feedback (LUDWIG, 1997; PARÉ et al., 2013). The Likert scale allowed evaluations according to the degree of importance (ROZADOS, 2015). In the $2^{\text {nd }}$ round, available from January 21 to February 19, 2019, the 24 questions that did not achieve satisfactory 80\% agreement (GRISHAM, 2009; HSU; SANDFORD, 2007; ARNETT-HARTWICK, 2018; MARQUES; FREITAS, 2018) were reviewed and resent, together with the results of the $1^{\text {st }}$ round, to the same set of the 1st round respondents. It was included together each question, all the opinions of the specialists, including the convergent and divergent ones, for their analysis.

\section{RESULTS}

Through card sorting, 11 respondents organized the cards with factors into groups that, according to their opinion, constituted the same orientation. Face and content validation were performed on the sub-constructs, with 37 items proposed. The agreement was calculated and the results were classified by the Kappa coefficient: $<0.00=$ Poor $; 0.00-0.20=$ Slight $; 0.21$ $0.40=$ Fair $; 0.41-0.60=$ Moderate $; 0.61-0.80=$ Substantial $; 0.81-1.00=$ Almost Perfect 
(LANDIS; KOCH, 1977). The values were calculated with the relative percentage of agreement within each group (responses in the item/participants). As a result, of the 37 items proposed, 31 remained, classified as "substantial" and almost perfect" (Table 2). The items "weak/poor" or "moderate", were excluded or associated with others. The items of "Culture of Information and Knowledge" framed as "moderate" have been adjusted and maintained, under the fear of impoverishing the research, considering that there will always be some area of disagreement "about the grouping of themes, terms of ambiguous conceptualization or terms that seem to have nowhere to fit in the structure" (FARIA, 2010, p.8), in which the group responsible for the final structure must base its definition, through theoretical and methodological basis.

Table 2-Card Sorting: Results

\begin{tabular}{|c|c|c|c|}
\hline QUESTIONS & Agreemt & $\begin{array}{l}\text { KAPPA } \\
\text { COEF }\end{array}$ & DIAGNOSIS \\
\hline $\begin{array}{l}\text { (CL) The intelligence process is conducted based } \\
\text { on the values of the leader. }\end{array}$ & $72.73 \%$ & Substantial & Good index. Maintain CL. \\
\hline $\begin{array}{l}\text { (CL) The leader has the sensitivity to recognize the } \\
\text { existence of different individual cultures. }\end{array}$ & $100.00 \%$ & $\begin{array}{l}\text { Almost } \\
\text { Perfect }\end{array}$ & Great index. Maintain CL. \\
\hline $\begin{array}{l}\text { (CL) The leader works to engage employees in } \\
\text { collecting information. }\end{array}$ & $81.82 \%$ & Substantial & Good index. Maintain CL. \\
\hline $\begin{array}{l}\text { (CL) The leader works to engage employees in } \\
\text { sharing information. }\end{array}$ & $81.82 \%$ & Substantial & Good index. Maintain CL. \\
\hline $\begin{array}{l}\text { (CL) The leader seeks to develop the cultural } \\
\text { values necessary to carry out the intelligence } \\
\text { process. }\end{array}$ & $81.82 \%$ & Substantial & Good index. Maintain CL. \\
\hline $\begin{array}{l}\text { (CTC) The relationship between employees is } \\
\text { based on collaboration. }\end{array}$ & $100.00 \%$ & $\begin{array}{l}\text { Almost } \\
\text { Perfect }\end{array}$ & Great index. Maintain CTC \\
\hline $\begin{array}{l}\text { (CTC) The relationship between employees is } \\
\text { based on trust. }\end{array}$ & $100.00 \%$ & $\begin{array}{l}\text { Almost } \\
\text { Perfect }\end{array}$ & Great index. Maintain CTC \\
\hline $\begin{array}{l}\text { (CTC) The relationship between employees is } \\
\text { based on the availability to work as a team. }\end{array}$ & $81.82 \%$ & $\begin{array}{l}\text { Almost } \\
\text { Perfect }\end{array}$ & Great index. Maintain CTC \\
\hline $\begin{array}{l}\text { (CTC) Information collection is based on the } \\
\text { availability of employees to work as a team. }\end{array}$ & $72.73 \%$ & Substantial & Good index. Maintain CTC \\
\hline $\begin{array}{l}\text { (CTC) Information sharing is based on the } \\
\text { availability of employees to work as a team. }\end{array}$ & $90.91 \%$ & $\begin{array}{l}\text { Almost } \\
\text { Perfect }\end{array}$ & Great index. Maintain CTC \\
\hline $\begin{array}{l}\text { (CC) Employees believe that the dissemination of } \\
\text { information depends on appropriate } \\
\text { communication. }\end{array}$ & $81.82 \%$ & $\begin{array}{l}\text { Almost } \\
\text { Perfect }\end{array}$ & Great index. Maintain CC \\
\hline $\begin{array}{l}\text { (CC) Employees believe that the dissemination of } \\
\text { knowledge depends on appropriate } \\
\text { communication. }\end{array}$ & $81.82 \%$ & $\begin{array}{l}\text { Almost } \\
\text { Perfect }\end{array}$ & Great index. Maintain CC \\
\hline $\begin{array}{l}\text { (CC) There are policies to encourage the } \\
\text { organization's employees to communicate ideas } \\
\text { and knowledge. }\end{array}$ & $72.73 \%$ & Substantial & Good index. Maintain CC \\
\hline $\begin{array}{l}\text { (CC) The leader engages employees to discuss } \\
\text { ideas in groups. }\end{array}$ & $100.00 \%$ & $\begin{array}{l}\text { Almost } \\
\text { Perfect } \\
(\mathrm{CL})\end{array}$ & $\begin{array}{l}\text { Great CL index. Reposition for } \\
\text { CL, for predominating values } \\
\text { pertinent to it. }\end{array}$ \\
\hline
\end{tabular}


(CC) The organization values the debate of ideas in groups as a driver of success in the intelligence process.

(CIK) Employees believe that the dissemination of information is an essential value for the success of the intelligence process.

\section{$36.36 \%$ Poor}

It was excluded, without losses, due to similarities with CTC, CC, CoIA, CLT and COFI.

Although "moderate", associating it with the CIK2 response, analyzing the understanding between CTC, $\mathrm{CC}, \mathrm{CIK}$ and CoIA, the item was excluded.

Re-analyzing, and verifying the

(CIK) Employees believe that the dissemination of knowledge is an essential value for the success of the intelligence process.

$45.45 \% \quad$ Moderate

$36.36 \%$ Poor understanding of CTC, CC, CIK and CoIA, the item was excluded.

Moderated in CIK, and maintained according to Faria

(CIK) There is a culture that values decision making based on shared information.

$45.45 \% \quad$ Moderate (2010), for presenting specificity, despite the ambiguity of theory.

(CIK) Employees have a common view that information sharing must be a systematic practice.

(CIK) Employees have a common view that knowledge sharing must be a systematic practice.

(CIK) Employees believe that the exploitation of information adds new ideas to the organization.

\begin{tabular}{|c|c|c|c|}
\hline & & & excluded. \\
\hline $\begin{array}{l}(\mathrm{CIK}) \text { There are policies to encourage information } \\
\text { sharing. }\end{array}$ & $54.55 \%$ & Moderate & Same as CIK3. \\
\hline $\begin{array}{l}\text { (CIK) There is a culture that values the process of } \\
\text { obtaining data and information. }\end{array}$ & $45.45 \%$ & Moderate & Same as CIK3. \\
\hline $\begin{array}{l}\text { (CoIA) Employees recognize the results of the } \\
\text { intelligence process as important to decision } \\
\text { making. }\end{array}$ & $72.73 \%$ & Substantial & Good index. Maintain CoIA. \\
\hline $\begin{array}{l}\text { (CoIA) Employees recognize the importance of } \\
\text { systematized intelligence practices in the } \\
\text { organization. }\end{array}$ & $100.00 \%$ & $\begin{array}{l}\text { Almost } \\
\text { perfect }\end{array}$ & Great index. Maintain CoIA. \\
\hline $\begin{array}{l}\text { (CoIA) Employees are aware that the results of the } \\
\text { intelligence process depend on the proper } \\
\text { execution of their activities. }\end{array}$ & $81.82 \%$ & $\begin{array}{l}\text { Almost } \\
\text { Perfect }\end{array}$ & Great index. Maintain CoIA. \\
\hline $\begin{array}{l}\text { (CoIA) Decision making is more agile due to the } \\
\text { implemented intelligence process. }\end{array}$ & $72.73 \%$ & Substantial & Good index. Maintain CoIA. \\
\hline $\begin{array}{l}\text { (CoIA) The tasks are executed more quickly, due } \\
\text { to the implemented intelligence process. }\end{array}$ & $63.64 \%$ & Substantial & Good index. Maintain CoIA. \\
\hline $\begin{array}{l}\text { (CoIA) The organization considers the intelligence } \\
\text { process as a driver of agility in responding and } \\
\text { adapting to environmental changes. }\end{array}$ & $72.73 \%$ & Substantial & Good index. Maintain CoIA. \\
\hline $\begin{array}{l}\text { (CLT) Employees recognize the importance of } \\
\text { seeking updating and training in intelligence } \\
\text { activities. }\end{array}$ & $72.73 \%$ & Substantial & Good index. Maintain CLT. \\
\hline $\begin{array}{l}\text { (CLT) Employees believe that training prepares } \\
\text { them to face changes in the environment. }\end{array}$ & $81.82 \%$ & $\begin{array}{l}\text { Almost } \\
\text { Perfect }\end{array}$ & Great index. Maintain CLT. \\
\hline $\begin{array}{l}\text { (CLT) Employees believe that analyzing } \\
\text { information in groups helps with learning. }\end{array}$ & $45.45 \%$ & Moderate & $\begin{array}{l}\text { Although "moderate", the item } \\
\text { was excluded. }\end{array}$ \\
\hline $\begin{array}{l}\text { (COFI) Employees explore information in search } \\
\text { of new ideas. }\end{array}$ & $72.73 \%$ & Substantial & Good index. Maintain COFI. \\
\hline
\end{tabular}

Same as CIK3.

$54.55 \%$ Moderate Same as CIK3.

Although "moderate", due to 45.45\% Moderate similarities with CC, CIC, CLT and COFI, the item was excluded.

.

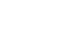

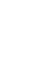




\begin{tabular}{llll}
$\begin{array}{l}\text { (COFI) Employees are engaged to develop an } \\
\text { anticipatory look, with a view to future scenarios. }\end{array}$ & $72.73 \%$ & Substantial & Good index. Maintain COFI. \\
\hline $\begin{array}{l}\text { (COFI) Employees observe possible warning signs } \\
\text { about the future of their business environment. }\end{array}$ & $81.82 \%$ & $\begin{array}{l}\text { Almost } \\
\text { Perfect }\end{array}$ & Great index. Maintain COFI. \\
\hline $\begin{array}{l}\text { (COFI) There are policies that encourage the } \\
\text { exposure of innovative ideas. }\end{array}$ & $100.00 \%$ & $\begin{array}{l}\text { Almost } \\
\text { Perfect }\end{array}$ & Great index. Maintain COFI. \\
\hline & $45.45 \%$ & Moderate & $\begin{array}{l}\text { Although "moderate", due to } \\
\text { ideas dispersed, the item was } \\
\text { excluded. }\end{array}$ \\
\hline
\end{tabular}

Source: Research Data

Later, the electronic Delphi was applied, in two rounds, with a predominance of agreement of $80 \%$ or more in the factors of the organizational culture that can influence intelligence processes. In the $1^{\text {st }}$ stage, 64 people started answering the questionnaire, and 54 completed it. Respondents were intelligence coordinators/managers (28\%), intelligence analysts/experts (31\%), independent professionals (20\%), intelligence students (10\%), intelligence professionals (9\%) and intelligence teachers (2\%). They belonged to the segments consulting (17\%), industry (17\%), education (13\%), technology (9\%), services (9\%), marketing $(6 \%)$, retail and distribution $(6 \%)$, others $(22 \%)$. After the $1^{\text {st }}$ round, a new version of the questionnaire was defined, reformulated according to the respondents' opinion, and sent back to the same people. The $2^{\text {nd }}$ round got 27 complete answers. For validation of the participants, Wright, Silva and Spers (2010) point out that 15 to 30 respondents indicate a sufficient number for relevant conclusions. Marques and Freitas (2018), point out 10 to 30 respondents, and Paré et al. (2013) indicate 7 to 30 . In the $1^{\text {st }}$ round of Delphi, participants received 31 statements on a Likert 7-point scale for judging the level of agreement. In the $1^{\text {st }}$ round, questions with $80 \%$ agreement were approved (GRISHAM, 2009; HSU; SANDFORD, 2007; ARNETTHARTWICK, 2018; MARQUES; FREITAS, 2018) on Likert scales 5, 6 and 7, with an average above 5.5 (PARÉ et al., 2013), representing an extremely strong level of agreement. In the $2^{\text {nd }}$ round, only the statements that did not reach $80 \%$ agreement in the $1^{\text {st }}$ round were forwarded, along with the arguments shared in the $1^{\text {st }}$ round. The $2^{\text {nd }}$ round also followed the option of qualitative reporting. As a result, a set of important factors was obtained, as shown below.

\subsection{CULTURE OF LEADERSHIP (CL)}

In the $1^{\text {st }}$ round, consensus was reached on statements CL3 (80\%) and CL6 (83\%), in agreement with Mason (2003), who indicates that it is up to the leader to lead the organizational culture. This is recognized among experts, both in engaging the team in the collection of 
information, and in encouraging the debate of ideas in groups. The importance that the leader exercises over the values, behaviors and beliefs of the group was also recognized, according to Trim and Lee (2006), who suggest that leaders must have sensitivity in the conduct of their team during the intelligence process. However, caveats of leaders' attitudes that occur in practice were presented, such as negligence in the collection, or too much emphasis on the collection but little analysis of information. The experts believe in the involvement of the leader in order to coordinate and motivate the team in the conduct of intelligence activities. A proactive, creative and diligent attitude is also considered relevant in the role of the leader.

In reference to the debate of ideas in groups and the leading role of the leader in the question of employee engagement in the debate, care and respect for diversity was observed, recognizing that a diverse team brings different points of view and experiences, generating better insights. One of the interviewees mentioned the reluctance of managers regarding diversity, which can lead to homogeneous teams, avoiding disagreements.

The statement "The leader works to engage employees in sharing information" has been changed to "The leader must work to engage employees in sharing information", reflecting the discrepancy between expectation and reality. It has been recognized phrases with still a matter to be strongly developed in organizations, but important for the culture of intelligence: "As absurd as it may seem, not every leader works to engage his team. Some treat their followers as $B$ professionals and want them this way. The true leader must treat and teach his followers to be A professionals". (Manager in Intelligence, Retail and Distribution).

The care in classifying information, confidential or not, was also highlighted. Mostly (93\%) there was a consensus that leaders must be sensitive and make efforts to share information, although still considered a sensitive topic: "Many leaders still believe that information is power. Few can observe that what gives them power is the intensive use of knowledge production to support decision making and resulting strategic actions." (Independent Intelligence Professional).

Currey, Somogy and Ariyawardana (2016) indicate that the leader must lead teams based on their values, especially confidence and intelligence awareness. During the interviews, the leader's motivating role in the entire intelligence process was also highlighted:

The leader has an influence on his employees and, often, on his peers and superiors. When the leader thinks 'outside the box', he analyzes, questions, seeks alternatives and stimulates the thinking of those around him to have the same synergy. Certainly, the team becomes more demanding, questioning and naturally creates a reasoning that strengthens the group and benefits the organization's objectives. (Intelligence, Marketing and Sales Coordinator). 
Hattula et al. (2015) state that culture management needs to address intercultural issues. This statement was addressed in the question "The leader possesses sensitivity to recognize the existence of different individual cultures", which was rewritten to "The leader who possesses sensitivity to recognize the existence of different cultures of his team becomes more capable of working with the intelligence process and its results". This change reflects the need for leaders to develop this capability and how important it is in the intelligence process: "[...] The leader needs to be prepared to identify and know the motivations and ambitions of each group/person, because this can help her/him in decision making, in relation to the use and appreciation of the talents that integrate her/his team." (Intelligence, Retail and Distribution Manager).

Based on the authors Currey, Somogy and Ariyawardana (2016), the leader is a driver of culture-changing behaviors. The statement "The leader must seek to develop, in her/his team, the values, beliefs and behaviors necessary to carry out the intelligence process" represents this argument, as well as the importance of the leader's performance with a team receptive to the values of the organizational culture: "The leader must seek to develop in her/his team, values, beliefs and behaviors, respecting the diversity of visions, cultures and opinions, in order to enrich the intelligence process." (Intelligence Coordinator, Industry and Retail Network).

The way the questions were presented in the $1^{\text {st }}$ round and rewritten in the $2^{\text {nd }}$ round signal cultural characteristics in the managers and specialists in intelligence. However, reality presents barriers to putting all these beliefs and values into practice. The second round led to the conclusion that, despite the current difficulties of organizations in which managers and employees still see the possession of information as a synonym for power, there is a strong awareness that it is essential for organizations to develop a culture of leadership aligned with the values of organization, market and intelligence. In addition, this leadership must be receptive and encouraging its teams, with values, behaviors and attitudes similar to the intelligence process, so that it can develop and evolve. The questions are shown on Table 3.

Table 3 - Delphi Results - Culture of Leadership (CL)

\begin{tabular}{|c|c|c|c|c|c|c|}
\hline & Question - Delphi Method - Round I & $\%$ & $\begin{array}{l}\text { Agr } \\
\text { eem } \\
t\end{array}$ & Question - Delphi Method - Round II & $\%$ & $\begin{array}{l}\text { A } \\
\text { gr } \\
\text { ee } \\
\text { mt }\end{array}$ \\
\hline $\begin{array}{l}\text { C } \\
\text { L1 }\end{array}$ & $\begin{array}{l}\text { The intelligence process is conducted } \\
\text { based on the values of the leader. }\end{array}$ & 72 & $\mathbf{N}$ & $\begin{array}{l}\text { The intelligence process must be } \\
\text { conducted based on the values of the } \\
\text { leader, which are in line with the } \\
\text { objectives of the organization, the } \\
\text { market and the intelligence. }\end{array}$ & 93 & $\mathbf{Y}$ \\
\hline $\begin{array}{c}\text { C } \\
\mathbf{L} 2\end{array}$ & $\begin{array}{l}\text { The leader has the sensitivity to } \\
\text { recognize the existence of different } \\
\text { individual cultures. }\end{array}$ & 76 & $\mathbf{N}$ & $\begin{array}{l}\text { The leader who has the sensitivity to } \\
\text { recognize the existence of different } \\
\text { cultures of her/his team becomes more }\end{array}$ & 93 & $\mathbf{Y}$ \\
\hline
\end{tabular}




\begin{tabular}{|c|c|c|c|c|c|c|}
\hline $\begin{array}{c}\text { C } \\
\mathbf{L 3}\end{array}$ & $\begin{array}{l}\text { The leader works to engage employees } \\
\text { in collecting information. }\end{array}$ & 80 & $\mathbf{Y}$ & - & & - \\
\hline $\begin{array}{c}\mathrm{C} \\
\mathrm{L4}\end{array}$ & $\begin{array}{l}\text { The leader works to engage employees } \\
\text { in sharing information. }\end{array}$ & 76 & $\mathbf{N}$ & $\begin{array}{l}\text { The leader must work to engage } \\
\text { employees in sharing information. }\end{array}$ & 93 & $\mathbf{Y}$ \\
\hline $\begin{array}{c}\text { C } \\
\text { L5 }\end{array}$ & $\begin{array}{l}\text { The leader seeks to develop, in her/his } \\
\text { the cultural values necessary to carry out } \\
\text { the intelligence process. }\end{array}$ & 72 & $\mathbf{N}$ & $\begin{array}{l}\text { The leader must seek to develop, in } \\
\text { her/his team, the values, beliefs and } \\
\text { behaviors (cultural components) } \\
\text { necessary to carry out the intelligence } \\
\text { process. }\end{array}$ & 85 & $\mathbf{Y}$ \\
\hline $\begin{array}{c}\text { C } \\
\text { L6 }\end{array}$ & $\begin{array}{l}\text { The leader engages employees to discuss } \\
\text { ideas in groups. }\end{array}$ & 83 & $\mathbf{Y}$ & - & - & - \\
\hline
\end{tabular}

Source: Research Data

\subsection{CULTURE OF TRUST AND COLLABORATION}

The characteristics addressed assess the relationship of the relationship between intelligence teams, and which must be aligned with trust (CEKULS, 2015a; CAPATINA et al., 2016), collaboration (MEUNIER-FITZHUGH; CAPATINA et al., 2016) and teamwork (CEKULS, 2015a; KANWAL; SINGH; SAMALIA, 2017). Assessments value collaboration as intrinsic to the organization's activities, in addition to the intelligence process: "Collaboration is the essence of good intelligence work." (Mentor Consulting, SCIP Member)

The trust was considered fundamental to the success of the intelligence process. However, individualism and competition were highlighted as threats. The relationship based on teamwork was highly valued: Teamwork needs to be better developed in companies. [...] It is up to the leader to propose projects that engage their groups to work together. Most of the time, it is still individualism that determines the working style of the groups (Intelligence, Marketing and Sales Coordinator). The need for alignment of many values stands out: "[...] it has all the other points: Everyone's engagement, respect, dedication, accepting differences, among others."(Intelligence Manager - Insurance Segment)

For Cekuls (2015a), trust is the key to the mutual information exchange. As for teamwork for the collection, analysis and sharing of information, albeit the agreement around $70 \%$, it was not the agreement level accepted in this survey (80\%). As stated by the respondents (Table 4), values of collaboration, trust and teamwork must be intrinsic to the whole organizational process: "The collection of information is a necessary task to be performed, even if there is no availability for teamwork." (Intelligence Coordinator, Industry and Retail Chain) 
Table 4 - Delphi Results - Culture of Trust and Collaboration (CTC)

\begin{tabular}{|c|c|c|c|c|c|c|}
\hline & Delphi Method - Round I & $\%$ & $\begin{array}{l}\text { A } \\
\text { gr } \\
\text { ee } \\
\text { mt }\end{array}$ & Delphi Method - Round I & $\%$ & $\begin{array}{l}\text { A } \\
\text { gr } \\
\text { ee } \\
\text { m } \\
\text { t }\end{array}$ \\
\hline $\begin{array}{l}\mathbf{C} \\
\mathbf{T} \\
\mathbf{C} 1\end{array}$ & $\begin{array}{l}\text { The relationship between employees is } \\
\text { based on collaboration. }\end{array}$ & 78 & $\mathbf{N}$ & $\begin{array}{l}\text { The relationship between employees must be } \\
\text { based on collaboration. }\end{array}$ & 100 & $\mathbf{Y}$ \\
\hline $\begin{array}{l}\mathbf{C} \\
\mathbf{T} \\
\mathbf{C} \\
\mathbf{2}\end{array}$ & $\begin{array}{l}\text { The relationship between employees is } \\
\text { based on trust. }\end{array}$ & 80 & $\mathbf{Y}$ & - & - & - \\
\hline $\begin{array}{l}\mathbf{C} \\
\mathbf{T} \\
\mathbf{C} \\
\mathbf{3}\end{array}$ & $\begin{array}{l}\text { The relationship between employees is } \\
\text { based on the availability to work as a } \\
\text { team. }\end{array}$ & 70 & $\mathbf{N}$ & $\begin{array}{l}\text { The relationship between employees must be } \\
\text { based on the availability to work as a team. }\end{array}$ & 96 & $\mathbf{Y}$ \\
\hline $\begin{array}{l}\mathrm{C} \\
\mathrm{T} \\
\mathrm{C} \\
\mathbf{4}\end{array}$ & $\begin{array}{l}\text { The collection of information is based } \\
\text { on the availability of employees to } \\
\text { work as a team. }\end{array}$ & 63 & $\mathbf{N}$ & $\begin{array}{l}\text { The collection of information must be based } \\
\text { on the availability of employees to work as a } \\
\text { team. }\end{array}$ & 67 & $\mathbf{N}$ \\
\hline $\begin{array}{l}\mathbf{C} \\
\mathbf{T} \\
\mathbf{C} \\
\mathbf{5}\end{array}$ & $\begin{array}{l}\text { Information sharing is based on the } \\
\text { availability of employees to work as a } \\
\text { team. }\end{array}$ & 76 & $\mathbf{N}$ & $\begin{array}{l}\text { Information sharing must be based on the } \\
\text { availability of employees to work as a team. }\end{array}$ & 74 & $\mathbf{N}$ \\
\hline $\begin{array}{l}\mathrm{C} \\
\mathrm{T} \\
\mathrm{C} \\
6\end{array}$ & - & - & - & $\begin{array}{l}\text { Information analysis must be based on the } \\
\text { availability of employees to work as a team. }\end{array}$ & 70 & $\mathbf{N}$ \\
\hline
\end{tabular}

Source: Research Data

\subsection{CULTURE OF COMMUNICATION}

With an almost unanimous result (94\%), the respondents agreed that the dissemination of both information and knowledge depends on appropriate communication (LIM; KLOBAS, 2000; CAPATINA; BLEOJU, 2012). In turn, we can see the importance that many specialists allocate to policies to encourage communication, which are still little realized in practice: "Communication is one of the main challenges for organizations that often fail in this regard. And companies don't always invest in policies to improve communication." (Intelligence Consultant and University Professor). However, care is taken not to confuse policies only as monetary incentives, but actions to promote team awareness must be promoted:

Encouraging the collection, exchange of information is important but you can't reward fundamental issues with money for a company. You can offer small commemorative internal events, but it must be clear the obligation of people to provide information for company development and attention to market signals. (Consultant in Intelligence - Education Area)

According to Burt and Heijden (2003), who affirm the importance of open and clear dialogues between the intelligence teams, there was an approach in reference to the experts' 
judgment on policies for communicating ideas and knowledge. With this, the question "there are policies to encourage the communication of ideas and knowledge by employees of the organization" was rewritten to "A culture conducive to the intelligence process must consider the importance of the existence and dissemination of policies to encourage the communication of ideas and knowledge by employees of the organization". The questions are on Table 5.

Table 5 - Delphi Results - Communication Culture (CC)

\begin{tabular}{|c|c|c|c|c|c|c|}
\hline & Delphi Method - Round I & $\%$ & $\begin{array}{l}\text { Agree } \\
\text { mt }\end{array}$ & Delphi Method - Round I & $\%$ & $\begin{array}{l}\text { A } \\
\text { gr } \\
\text { ee } \\
\text { mt }\end{array}$ \\
\hline $\begin{array}{l}\mathrm{C} \\
\mathbf{C} \\
\mathbf{1}\end{array}$ & $\begin{array}{l}\text { Employees believe that the dissemination } \\
\text { of information depends on appropriate } \\
\text { communication. }\end{array}$ & 94 & $\mathbf{Y}$ & - & - & - \\
\hline $\begin{array}{l}\text { C } \\
\text { C } \\
\mathbf{2}\end{array}$ & $\begin{array}{l}\text { Employees believe that the dissemination } \\
\text { of knowledge depends on appropriate } \\
\text { communication. }\end{array}$ & 94 & $\mathbf{Y}$ & - & - & - \\
\hline $\begin{array}{l}\mathbf{C} \\
\mathbf{C} \\
\mathbf{3}\end{array}$ & $\begin{array}{l}\text { There are policies to encourage the } \\
\text { organization's employees to communicate } \\
\text { ideas and knowledge. }\end{array}$ & 57 & $\mathbf{N}$ & $\begin{array}{l}\text { A culture propitious to the } \\
\text { intelligence process must consider } \\
\text { the importance of the existence and } \\
\text { dissemination of policies to encourage } \\
\text { the communication of ideas and } \\
\text { knowledge by the organization's } \\
\text { employees. }\end{array}$ & 89 & $\mathbf{Y}$ \\
\hline
\end{tabular}

Source: Research Data

\subsection{CULTURE OF INFORMATION AND KNOWLEDGE}

Composed by issues related to the recognition of information and knowledge sharing (VIVIERS; SAAYMAN; MULLER, 2005; LEE; TRIM, 2008; CAPATINA; BLEOJU, 2012; HATTULA et al., 2015; CEKULS, 2015a), all issues on this topic were rewritten, but were all approved in the $2^{\text {nd }}$ round (over $80 \%$ consensus). It was identified, based on comments from the $1^{\text {st }}$ round, that this culture is considered important, but it is still being gradually introduced in organizations. As a result of the analysis, it is identified that the culture of information and knowledge involves characteristics that are increasingly valued by organizations, such as the process of searching for data and information; decision-making based on shared information; the importance of employees having a common vision that the sharing of INFORMATION and the sharing of KNOWLEDGE must be systematic practices; the importance of the existence and dissemination of policies to encourage the sharing of Information in the Organization.

Regarding the importance that the organizational culture propitious to intelligence involves decision-making based on shared information, statements indicate that this is a process in recognition in companies, which is why some say it is not yet applied, although it is identified that intelligence managers believe in its importance: "There are still closed professional 
profiles, however the organizational culture and the new generations must be able to reinforce the importance of sharing information and decisions." (Specialist in Intelligence-Media Area)

In the $1^{\text {st }}$ round, experts show that there is still a lot of work to be done: "This is a cultural work that sometimes takes a lot of practice and time to reach the ideal level." (Mentor Consulting and SCIP Member). The alignment with the role of the leader, aiming to encourage employees to adhere to the common value that sharing must be systematic and inherent to the entire organization: "[...] Many employees have neither interest nor access to this type of organizational culture. It is up to the leader to encourage them to engage in this development of systematic information exchange." (Intelligence, Marketing and Sales Coordinator)

In the $1^{\text {st }}$ round, important points were appointed about the incentive of policies, in the sense that these ones must act in a win-win culture, recognizing the shared intrinsic value. In the $2^{\text {nd }}$ round, on the other hand, there were an emphasis in relation to the enhancement of the employees' professional profile and skills: "[...] The important thing is the appreciation (real, not forced) of the professional profile that you share." (Intelligence Specialist - Media)

Regarding the organization's recognition of data and information gathering practices, this still constitutes a value in formation in most organizations, and must be associated with other values. It is clear that the culture of information and knowledge has characteristics highly valued by experts in intelligence. However, they encompass values that, important as they are, still require an effort to implement them in organizations. Table 6 presents the list of questions.

Table 6 - Delphi Results - Culture of Information and Knowledge (CIK)

\begin{tabular}{|c|c|c|c|c|c|c|}
\hline & Delphi Method - Round I & $\%$ & $\begin{array}{l}\text { A } \\
\text { gr } \\
\text { ee } \\
\text { mt }\end{array}$ & Delphi Method - Round I & $\%$ & $\begin{array}{l}\text { A } \\
\text { gr } \\
\text { ee } \\
\text { mt }\end{array}$ \\
\hline $\begin{array}{l}\mathbf{C I} \\
\mathbf{K} \\
\mathbf{1}\end{array}$ & $\begin{array}{l}\text { There is a culture that values } \\
\text { decision making based on shared } \\
\text { information. }\end{array}$ & 61 & $\mathbf{N}$ & $\begin{array}{l}\text { A culture propitious to the intelligence process } \\
\text { must value decision making based on shared } \\
\text { information. }\end{array}$ & 93 & $\mathbf{Y}$ \\
\hline $\begin{array}{l}\mathbf{C I} \\
\mathbf{K} \\
\mathbf{2}\end{array}$ & $\begin{array}{l}\text { Employees have a common view } \\
\text { that information sharing must be a } \\
\text { systematic practice. }\end{array}$ & 63 & $\mathbf{N}$ & $\begin{array}{l}\text { A culture propitious to the intelligence process } \\
\text { must consider the importance of employees } \\
\text { having a common vision that information } \\
\text { sharing must be a systematic practice. }\end{array}$ & 93 & $\mathbf{Y}$ \\
\hline $\begin{array}{l}\mathbf{C I} \\
\mathbf{K} \\
\mathbf{3}\end{array}$ & $\begin{array}{l}\text { Employees have a common view } \\
\text { that knowledge sharing must be a } \\
\text { systematic practice. }\end{array}$ & 70 & $\mathbf{N}$ & $\begin{array}{l}\text { A culture propitious to the intelligence process } \\
\text { must consider the importance of employees } \\
\text { having a common vision that knowledge sharing } \\
\text { must be a systematic practice. }\end{array}$ & 96 & $\mathbf{Y}$ \\
\hline $\begin{array}{l}\text { CI } \\
\mathbf{K} \\
4\end{array}$ & $\begin{array}{l}\text { There are policies to encourage } \\
\text { information sharing. }\end{array}$ & 46 & $\mathbf{N}$ & $\begin{array}{l}\text { A culture propitious to the intelligence process } \\
\text { must consider the importance of the existence } \\
\text { and dissemination of policies to encourage the } \\
\text { sharing of Information in the Organization. }\end{array}$ & 96 & $\mathbf{Y}$ \\
\hline $\begin{array}{l}\mathbf{C I} \\
\mathbf{K} \\
\mathbf{5}\end{array}$ & $\begin{array}{l}\text { There is a culture that values the } \\
\text { process of obtaining data and } \\
\text { information. }\end{array}$ & 61 & $\mathbf{N}$ & $\begin{array}{l}\text { A culture propitious to the intelligence process } \\
\text { must value the process of searching for data and } \\
\text { information. }\end{array}$ & 96 & $\mathbf{Y}$ \\
\hline
\end{tabular}

Source: Research Data 


\subsection{CULTURE OF INTELLIGENCE AWARENESS}

Despite some disagreements, $80 \%$ of respondents (Table 7) stated that they have the belief that the intelligence process brings agility to decision making, as suggested by Kanwal, Singh and Samalia (2017). After rewriting, it was unanimous that a propitious intelligence culture must consider the importance of all members recognizing the results of decision making, according to Viviers, Saayman and Muller (2005) and Jaharuddin, Mansor and Yaakob (2016a). However, it faces obstacles in practice, with the affirmations: "The results are recognized individually, without a clear expression of recognition by the organization." (Intelligence Student - Information Technology), and "Some employees are, others are not aware of how the decision-making processes work, nor do they identify their own importance in this process." (Intelligence, Marketing and Sales Coordinator)

The belief of the intelligence process speeds up the execution of the organization's tasks (KANWAL; SINGH; SAMALIA, 2017) has not been confirmed by the experts. There is, however, a high-level agreement (96\%) that a culture propitious to the intelligence process must consider that employees recognize the importance of systematized intelligence practices (JAHARUDDIN; MANSOR; YAAKOB, 2016a). However, in the reality: "There is already a movement in Brazil in this direction, but we cannot say that this recognition is prevalent in most companies, mainly in top management." (Independent Intelligence Professional)

Regarding the employees' awareness that the results of the intelligence process depend on the proper execution of their activities (JAHARUDDIN; MANSOR; YAAKOB, 2016a), although important, it is still a delicate issue for organizations: "Many employees are unaware of the degree of importance of their work in the company's process. It is up to the leader to clarify and engage everyone in the cause." (Intelligence, Marketing and Sales Coordinator)

Regarding the belief that the organization must consider intelligence as a driver of agility in responding and adapting to environmental changes (KANWAL; SINGH; SAMALIA, 2017), 96\% believe this. However, the confrontation between expectation vs reality is faced: "Companies that have a systematized intelligence process naturally understand how much this process favors agility in decision making and the possibility of forecasting various scenarios and preparing to act in each one of them." (Intelligence, Marketing and Sales Coordinator), but "Few companies are aware of this in Brazil." (Intelligence Consultant - Education Area) 
Table 7 - Delphi Results - Culture of Intelligence Awareness (CoIA)

\begin{tabular}{|c|c|c|c|c|c|c|}
\hline & Delphi Method - Round I & $\%$ & $\begin{array}{l}\text { A } \\
\text { gr } \\
\text { ee } \\
\text { mt }\end{array}$ & Delphi Method - Round I & $\%$ & $\begin{array}{l}\text { A } \\
\text { gr } \\
\text { ee } \\
\text { mt }\end{array}$ \\
\hline $\begin{array}{l}\text { C } \\
\text { oI } \\
\text { A } \\
1\end{array}$ & $\begin{array}{l}\text { Employees recognize the results of } \\
\text { the intelligence process as } \\
\text { important to decision making. }\end{array}$ & 74 & $\mathbf{N}$ & $\begin{array}{l}\text { A culture propitious to the intelligence } \\
\text { process must consider the importance that } \\
\text { employees recognize the results of this } \\
\text { intelligence process as important to decision } \\
\text { making. }\end{array}$ & 100 & $\mathbf{Y}$ \\
\hline $\begin{array}{l}\text { C } \\
\text { oI } \\
\text { A } \\
2\end{array}$ & $\begin{array}{l}\text { Employees recognize the } \\
\text { importance of systematized } \\
\text { intelligence practices in the } \\
\text { organization. }\end{array}$ & 69 & $\mathbf{N}$ & $\begin{array}{l}\text { A culture propitious to the intelligence } \\
\text { process must consider that employees must } \\
\text { recognize the importance of systematized } \\
\text { intelligence practices in the organization. }\end{array}$ & 96 & $\mathbf{Y}$ \\
\hline $\begin{array}{l}\text { C } \\
\text { oI } \\
\text { A } \\
3\end{array}$ & $\begin{array}{l}\text { Employees are aware that the } \\
\text { results of the intelligence process } \\
\text { depend on the proper execution of } \\
\text { their activities. }\end{array}$ & 70 & $\mathbf{N}$ & $\begin{array}{l}\text { A culture propitious to the intelligence } \\
\text { process must consider the importance that } \\
\text { employees must be aware that the results of } \\
\text { the intelligence process depend on a proper } \\
\text { execution of their activities. }\end{array}$ & 93 & $\mathbf{Y}$ \\
\hline $\begin{array}{l}\text { C } \\
\text { oI } \\
\text { A } \\
4\end{array}$ & $\begin{array}{l}\text { Decision making is more agile due } \\
\text { to the implemented intelligence } \\
\text { process. }\end{array}$ & 80 & $\mathbf{Y}$ & 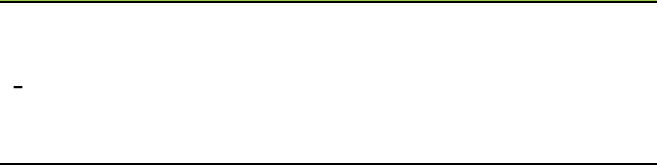 & - & - \\
\hline $\begin{array}{l}\text { C } \\
\text { oI } \\
\mathbf{A} \\
\mathbf{5}\end{array}$ & $\begin{array}{l}\text { The tasks are executed more } \\
\text { quickly, due to the implemented } \\
\text { intelligence process. }\end{array}$ & 72 & $\mathbf{N}$ & $\begin{array}{l}\text { It is believed that the intelligence process } \\
\text { speeds up the execution of tasks of the } \\
\text { organization in general. }\end{array}$ & 67 & $\mathbf{N}$ \\
\hline $\begin{array}{l}\text { C } \\
\text { oI } \\
\text { A } \\
6\end{array}$ & $\begin{array}{l}\text { The organization considers the } \\
\text { intelligence process as a driver of } \\
\text { agility in responding and adapting } \\
\text { to environmental changes. }\end{array}$ & 70 & $\mathbf{N}$ & $\begin{array}{l}\text { The organization must consider the } \\
\text { intelligence process as a driver of agility in } \\
\text { responding and adapting to environmental } \\
\text { changes. }\end{array}$ & 96 & $\mathbf{Y}$ \\
\hline
\end{tabular}

Source: Research Data

\subsection{CULTURE OF LEARNING AND TRAINING}

Respondents (Table 8) agree that training prepares them to face changes in the environment, based on Araújo, Costa and Aparício (2017). However, it depends on other factors: "[...] The development of training depends on the stimulation of the organizational culture and its leader." (Intelligence, Marketing and Salles Coordinator). It is noticed the belief that training and updating in intelligence is important, in consent with Viviers, Saayman and Muller (2005) and Sewdass and Du Toit (2014): “Continuous training is an essential factor for modern organizations." (Intelligence Specialist - Media).

However, it is still important that organizations value training more:

I see that they recognize, but there is not always money for that in the company, and they are not willing to spend what a good intelligence course is worth with their own investment. They invest $\mathrm{R} \$ 3,000.00$ in a new cell phone, but find it expensive to invest around R\$ 1,600.00 in training. (Independent Intelligence Professional) 
Table 8 - Delphi Result - Culture of Learning and Training (CLT)

\begin{tabular}{llllll} 
Delphi Method - Round I & $\% \begin{array}{l}\text { Agr } \\
\text { eem } \\
\mathbf{t}\end{array}$ & Delphi Method - Round I & $\begin{array}{l}\text { Agr } \\
\text { eem } \\
\text { ent }\end{array}$ \\
\hline $\begin{array}{l}\text { Employees recognize the } \\
\begin{array}{l}\text { importance of seeking updating } \\
\text { and training in intelligence } \\
\text { activities. }\end{array}\end{array}$ & $\mathbf{6 9}$ & $\mathbf{N}$ & $\begin{array}{l}\text { A culture propitious to the intelligence process } \\
\text { must consider the importance of employees } \\
\text { recognizing the importance of seeking updating and } \\
\text { training in intelligence activities. }\end{array}$ & $\mathbf{8 5}$ & $\mathbf{Y}$ \\
\hline $\begin{array}{l}\text { Employees believe that training } \\
\text { prepares them to face changes in } \\
\text { the environment. }\end{array}$ & $\mathbf{8 5}$ & $\mathbf{Y}$ & - & - & - \\
\hline
\end{tabular}

Source: Research Data

\subsection{CULTURE OF ORIENTATION TO THE FUTURE AND INNOVATION}

According to the $1^{\text {st }}$ round, this culture is still under development (Table 9). From the $2^{\text {nd }}$ round on, it is clear that this culture is valued, but still requires development and belief in the exploration of information in search of new ideas:

"We still have a lot to explore in analysis, as the area still generates a lot of information and disseminates it without properly exploring it." (Intelligence Specialist - Port Services)

"Here is always the big key to success. The more information we have, the more 'questions' are asked. The challenge is to know the 'time to stop' and make the decision with 'what we have managed to bring together." (Insurance Market Intelligence Manager)

As for the shared view that employees must be engaged to develop an anticipatory look, with a view to future scenarios (BURT; HEIJDEN, 2003; MASON, 2003), despite the high level of agreement in the second round of research, there is difficulty in aligning this factor to the organizational culture, according the interviewed specialists: "It depends on the employee's profile, the leadership style and the organization's culture" (Intelligence, Marketing and Sales Coordinator); "The strategic planning processes and scenarios favor a small group within organizations, most of them have no idea what is going on, what the company wants, where it is going to" (Intelligence Consultant - Education)

Regarding the topic of warning signs (LESCA, 2003; MASON, 2003), despite the agreement level in the $2^{\text {nd }}$ round, difficulties are perceived: "It is the duty of the intelligence team, but employees, in general, have no idea of that." (Intelligence Consultant - Education)

In reference to policies that encourage the exhibition of innovative ideas, these are considered fundamental for innovation, according to Vishnevskiy, Karasev and Meissner (2015), Kanwal, Singh and Samalia (2017): "Innovation is a critical success factor for 
intelligence processes" (Intelligence Consultant of Education) and "The culture of encouraging attempts and not being afraid of mistakes is essential." (Intelligence Specialist - Media)

Table 9 - Delphi Results - Culture of Orientation to the Future and Innovation (COFI)

\begin{tabular}{|c|c|c|c|c|c|c|}
\hline & Delphi Method - Round I & $\%$ & $\begin{array}{l}\text { A } \\
\text { gr } \\
\text { ee } \\
\text { mt }\end{array}$ & Delphi Method - Round I & $\%$ & $\begin{array}{l}\text { A } \\
\text { gr } \\
\text { ee } \\
\text { mt }\end{array}$ \\
\hline $\begin{array}{l}\text { C } \\
\text { O } \\
\text { FI } \\
1\end{array}$ & $\begin{array}{l}\text { Employees explore information in } \\
\text { search of new ideas. }\end{array}$ & 74 & $\mathbf{N}$ & $\begin{array}{l}\text { A culture propitious to the intelligence } \\
\text { process must consider the importance that } \\
\text { employees explore information in search of } \\
\text { new ideas. }\end{array}$ & 93 & $\mathbf{Y}$ \\
\hline $\begin{array}{c}\text { C } \\
\text { O } \\
\text { FI } \\
2\end{array}$ & $\begin{array}{l}\text { Employees are engaged to develop an } \\
\text { anticipatory look, with a view to } \\
\text { future scenarios. }\end{array}$ & 61 & $\mathbf{N}$ & $\begin{array}{l}\text { A culture that is conducive to the } \\
\text { intelligence process must consider the } \\
\text { importance of employees being engaged in } \\
\text { developing an anticipatory look, with a view } \\
\text { to future scenarios. }\end{array}$ & 96 & $\mathbf{Y}$ \\
\hline $\begin{array}{c}\text { C } \\
\text { O } \\
\text { FI } \\
\mathbf{3}\end{array}$ & $\begin{array}{l}\text { Employees observe possible warning } \\
\text { signs about the future of their business } \\
\text { environment. }\end{array}$ & 65 & $\mathbf{N}$ & $\begin{array}{l}\text { A culture propitious to the intelligence } \\
\text { process must consider the importance that } \\
\text { employees observe possible warning signs } \\
\text { about the future of their business } \\
\text { environment. }\end{array}$ & 100 & $\mathbf{Y}$ \\
\hline $\begin{array}{l}\text { C } \\
\text { O } \\
\text { FI } \\
4\end{array}$ & $\begin{array}{l}\text { There are policies that encourage the } \\
\text { exposure of innovative ideas. }\end{array}$ & 65 & $\mathbf{N}$ & $\begin{array}{l}\text { A culture propitious to the intelligence } \\
\text { process must consider the importance of } \\
\text { the existence of policies that foster the } \\
\text { exposure of innovative ideas. }\end{array}$ & 96 & $\mathbf{Y}$ \\
\hline
\end{tabular}

Source: Research Data

In summary, Table 10 presents the general roadmap of factors of the Organizational Culture that can influence the intelligence process.

Table 10 - Roadmap of Culture of Intelligence Factors in Organizations

\begin{tabular}{ll}
\multicolumn{1}{c}{ Culture } & \multicolumn{1}{c}{ Culture of Intelligence Factors in Organizations } \\
\hline & 1) The intelligence process must be conducted based on the values of the leader, which are \\
in line with the objectives of the organization, the market and the intelligence. \\
2) The leader with sensitivity to recognize the existence of different team cultures, becomes \\
more capable of working with the intelligence process. \\
3) The leader must engage employees in collecting information. \\
4) The leader must engage employees in sharing information. \\
5) The leader must seek to develop, in her/his team, the values, beliefs and behaviors \\
necessary to carry out the intelligence process. \\
6) The leader must engage employees to brainstorm in groups. \\
Culture and \\
7) The relationship between employees must be based on collaboration. \\
8) The relationship between employees must be based on trust. \\
9) The relationship between employees must be based on the availability to work as a team.
\end{tabular}




\begin{tabular}{|c|c|}
\hline & $\begin{array}{l}\text { 15) A culture conducive to the intelligence process must consider the importance of } \\
\text { employees having a common vision that information sharing must be a systematic practice. } \\
\text { 16) A culture conducive to the intelligence process must consider the importance of } \\
\text { employees having a common vision that knowledge sharing must be a systematic practice. } \\
\text { 17) A culture propitious to the intelligence process must consider the existence and } \\
\text { dissemination of policies to encourage the sharing of information in the organization. }\end{array}$ \\
\hline $\begin{array}{l}\text { Intelligence } \\
\text { Awareness }\end{array}$ & $\begin{array}{l}\text { 18) A culture propitious to the intelligence process must consider that employees recognize } \\
\text { the results of the intelligence process as important to decision-making. } \\
\text { 19) A culture propitious to the intelligence process must consider that employees recognize } \\
\text { the importance of systematized intelligence practices in the organization. } \\
\text { 20) A culture propitious to the intelligence process must consider that employees must be } \\
\text { aware that the results of the intelligence process depend on a proper execution of their } \\
\text { activities. } \\
\text { 21) The organization must consider the intelligence process as a driver of agility in } \\
\text { responding and adapting to environmental changes. }\end{array}$ \\
\hline $\begin{array}{l}\text { Learning and } \\
\text { Training }\end{array}$ & $\begin{array}{l}\text { 22) A culture propitious to the Intelligence process must consider that employees recognize } \\
\text { the importance of seeking updating and training in intelligence activities. } \\
\text { 27) In a culture propitious to the intelligence process, employees must believe that the } \\
\text { training prepares them to face environmental changes. }\end{array}$ \\
\hline $\begin{array}{l}\text { Orientation to } \\
\text { the Future and } \\
\text { Innovation }\end{array}$ & $\begin{array}{l}\text { 23) A culture propitious to the intelligence process must consider that employees explore } \\
\text { information in search of new ideas. } \\
\text { 24) A culture propitious to the intelligence process must consider that employees are } \\
\text { engaged in developing an anticipatory look, with vision of future scenarios. } \\
\text { 25) A culture conducive to the intelligence process must consider it important that } \\
\text { employees observe possible warning signs about the future of their business environment. } \\
\text { 26) A culture propitious to the intelligence process must consider the existence of policies } \\
\text { that foster the exposure of innovative ideas. }\end{array}$ \\
\hline
\end{tabular}

The research shows the importance given by experts to the factors presented, in addition to showing a gap between what is expected from the organizational culture of intelligence and the reality. The script of factors of organizational culture, associated with sub-constructs that form the intelligence culture, and validated by specialists, answers the objective of this research.

\section{FINAL REMARKS}

This work aimed to identify and evaluate the features of the organizational culture that influence structured processes of intelligence in organizations. There is a need for studies to identify the human and institutional factors prior to the adoption of intelligence processes in organizations, in order to point out behavioral elements, beliefs and values of individuals and teams that may be related to the success or failure of the process. Through the systematic literature review, cultures of leadership, collaboration and trust, of communication, of information and knowledge, of learning and training, of awareness of intelligence, and oriented to the future and innovation were identified. With the validation of the factors, cultural factors valued by intelligence specialists were identified, showing the importance of the theme in research in the area of Information Systems, in academic and practical-organizational terms. 
In terms of culture of leadership, the leader is expected to have values related to those of the organization, the market and intelligence, being engaged in dealing with her/his teams so that they perceive these values and follow them. A good leader also needs to deal with the cultures of each member of her/his teams, balancing the diversity of ideas and values, and turning diversity into a positive factor in the intelligence process. Other factors associated with the leader, such as engagement in the collection, sharing and debate of ideas in groups, are highlighted. In addition, the leader must develop, in her/his team, values, beliefs and behaviors necessary for the realization of the intelligence process.

As for the culture of trust and collaboration, it is identified as necessary for the entire organization, and not only in activities of information collection, sharing and analysis, being associated with the leader, the sensitivity to understand the level of data and information handling and which groups to share. Characteristics of individualism and fear of others' development were also perceived, in addition to feeling of possession of information as a synonym for power. Therefore, good intelligence management must transcend these values, in order to better align with the characteristics of the teams. Teamwork availability is also valued.

The culture of communication involves appropriate exchanges, with targeted and clear conversations aimed at providing improvements for sharing information such as knowledge construction. The disclosure of policies to encourage communication by employees is considered relevant, in the sense of valuing the profiles, skills of employees and the intrinsic value of what is being shared among them. In relation to the culture of information and knowledge, there is still a latent difficulty in the current organizations regarding the implantation of this culture, still under construction. Employees must consider sharing information and knowledge as systematic practices, valuing the process of searching for data and information, and making decisions based on shared information. The disclosure of information sharing incentive policies is also valued by respondents.

The culture of intelligence awareness is considered relevant, and employees value intelligence results for decision making, considering that these results depend on the proper execution of their activities. In addition, this culture considers the importance of systematized intelligence practices, and the intelligence process as a driver of agility in response and adaptation to environmental changes. In the culture of learning and training, employees recognize the importance of updating in intelligence, and training prepares them to face changes in the environment. However, it is important that organizations consider training not just a mere expense, but an investment for their teams. As for the culture oriented to future and innovation, it is still recent in organizations. It covers beliefs and values that teams explore 
information in search of new ideas, engaged in developing an anticipatory look, with vision of future scenarios, attentive to the observation of warning signs about an environment still under construction, and which organization can foresee policies to foster innovative ideas.

With the debate on cultural factors that can influence the success of the intelligence process, associated with the opinions of specialists in the area, it was possible to identify cultural development needs among the teams in the organizations. As it is a broad and sensitive theme, organizational culture involves factors that must be monitored and adjusted according to new findings in the academy. As a contribution in the academic field, this work brings together factors of the organizational culture that can influence the success of the intelligence processes. In applied terms, it is believed that it is possible, with the set of factors identified, to consider and assess the strengths and weaknesses of human factors for the realization of the intelligence process. An application of the same would allow mapping the factors that deserve attention and allow advances in the intelligence process in the organization.

In terms of limitations, the sample of respondents used for the survey reproduces a range of ideas and opinions. The databases of data searches have not been exhausted, which is why there is room for further investigation of other cultural elements important to the processes of intelligence in organizations. As a proposal for future studies, the cultural factors detected could be analyzed in greater depth within the organizations' practice, in order to expand knowledge on the subject. In terms of future research based on the limitations, studies are indicated considering the opinions of specialists worldwide, since this research has privileged Brazilians working in Brazilian organizations. Differences between cultures of organizations that use intelligence processes can also represent a productive field for studies.

\section{REFERENCES}

AGHA, S.; ATWA, E.; KIWAN, S. The Impact of Strategic Intelligence on Firm Performance and the Mediator Role of Strategic Flexibility: An Empirical Research in Biotechnology Industry. International Journal of Management, v. 1, n. 5, p. 65-72, 2014.

ALMEIDA, F.C.; LESCA, H.; CANTON, A.W.P. Intrinsic motivation for knowledge sharing - competitive intelligence process. Journal Knowledge Management, v.20, n.6, 2016.

ARAÚJO, H.; COSTA, C.J.; APARÍCIO, M. Modelo de Competitive Intelligence (CI) Competitive Intelligence (CI) Model. 12th Iberian Conference on Information Systems and Technologies, Portugal, Lisbon, 2017. 
AREFIN, S.; HOQUE, R.; BAO, Y. The impact of business intelligence on organization's effectiveness: an empirical study. Journal of Systems and Information Technology, v.17, n.3, p.263-285, 2015.

ARNETT-HARTWICK, S. E. Experiences to Develop Globally Competent Family and Consumer Sciences Teachers: A Delphi Study. Journal of Education and Human Development, v.7, n.2, p.112-128, 2018.

ASGHARI, S.; TARGHOLI, S.; KAZEMI, A.; SHAHRIYARI, S., RAJABION, L. A new conceptual framework for identifying the factors influencing the effectiveness of competitive intelligence. Competitiveness Review, 2020.

BORGES, N.M.; JANISSEK-MUNIZ, R. The environmental scanning as an informal and individual practice in organizations. A view based on the Illusion of Control's Theory. In: $\mathbf{9}^{\mathbf{0}}$ IFBAE, Poitiers, 2017.

BURT, G.; HEIJDEN, K. First steps: towards purposeful activities in scenario thinking and future studies. Futures, v.35, p.1011-1026, 2003.

CAINELLI, A.S. Proposta de Ferramenta para Diagnóstico de Práticas Antecedentes à Adoção da Atividade de Inteligência nas Organizações. Dissertation: UFRGS, 2018.

CALOF, J. Canadian competitive intelligence practices: a study of practicing strategic and competitive intelligence professionals' Canadian members. Foresight, 2017.

CAPATINA, A.; BLEOJU, G. Organisational instructional communication as a cultural based competitive intelligence tool. $\mathbf{1 3}^{\text {th }}$ European Conf. on Knowledge Management, 2012.

CAPATINA, A.; BLEOJU, G.; YAMAZAKI, K.; ROZALIA, N. Cross-cultural strategic intelligence solutions for leveraging open innovation opportunities. Journal of Intelligence Studies Business, v.6, n.3, p.27-38, 2016.

CARON-FASAN, M.-L.; JANISSEK-MUNIZ, R. Análise de informações de Inteligência estratégica antecipativa coletiva: proposição de um método, caso aplicado e experiências. RAUSP, v.39, n.3, p.205-219, 2004.

CASARTELli, A. O.; RODRIGUES, A.C.M.; BITTENCOURT, H.R.; GARIBOTTI, V. Inteligência estratégica em instituições de ensino superior. Perspectivas em Ciência da Informação, v.15, n.2, p.183-197, 2010.

CEKULS, A. Culture of Knowledge Sharing in Terms of Competitive Intelligence in Organizations. Proceedings of the 2015 International Conference "Economic Science for Rural Development", 2015a.

CEKULS, A. Leadership Values in Transformation of Organizational Culture to Implement Competitive Intelligence Management. European Integration Studies, n.9, p.244-256, 2015 b.

CHÉR, R. Engajamento - Melhores práticas de Liderança, Cultura Organizacional e Felicidade no Trabalho. São Paulo: Alta Books, 2 ed. 2016. 
CHERMACK, T.; NIMON, K. Drivers and outcomes of scenario planning: a canonical correlation analysis. European Journal of Training and Development, v.37, n.9, 2013.

CHIRU, I. Engaging public support and awareness in intelligence: The demands and challenges to developing an intelligence culture. International Journal Intelligence, v.29, n.3, 2016.

CHOO, C.W. Environmental scanning as information seeking and organizational learning. Information Research, v.7 n.1, p.1-37, 2001.

CURREY, P.; SOMOGY, S.; ARIYAWARDANA, A. Why Organizations Struggle to Implement a Market Orientation: Insights into beliefs of top management. Journal Food Product Mkt, v.23, p.783-798, 2016.

DAVENPORT, T.H. Ecologia da Informação: porque só a tecnologia não basta para o sucesso na era da informação. Oxford, 1998.

DUAN, Y.; CAO, G.; EDWARDS, J.S. Understanding the impact of Business Analytics on Innovation. European Journal of Operational Research, 2018.

DU TOIT, A. Using environmental scanning to collect strategic information: A South African survey. International Journal of Information Management, v.36, p.16-24, 2016.

DUUS; H. J. Strategic forecasting: the management perspective, Management Research Review, v.39, n.9, p.998-1015, 2016.

ESTEBAN-NAVARRO, M. A.; GARCÍA-MADURGA, M. A. Estudio exploratorio sobre la percepción de la gestión de la Inteligencia Competitiva por los directivos en empresas aragonesas sin una práctica sistematizada. Revista Española de Documentación Científica, v. 42, n. 3, ed. 239, p. 1-19, 2019.

FARIA, M.M. Card Sorting: noções sobre a técnica para teste e desenvolvimento de categorizações e vocabulários. Revista Digital de Biblioteconomia e Ciência da Informação, v.7, n.2, p.1-9, 2010.

FULD, L.M. The new competitor intelligence: the complete resource for finding, analyzing, and using information about your competitors. New York: Wiley, 1995.

GARCIA-ALSINA, M.; COBARSÍ-MORALES, J.; ORTOLL, E. Competitive intelligence theoretical framework and practices: The case of Spanish universities. Journal of Information Management, v.68, n.1, 2016.

GASPARETTO, L.E. Como construir equipes fantásticas. São Paulo: Phorte Editora, 2017.

GRISHAM, T. The Delphi technique: a method for testing complex and multifaceted topics. International Journal of Managing Projects in Business, v.2 n.1, p.112-130, 2009.

HAMMOUD, M.S.; NASH, D. What corporations do with foresight. European Journal Futures Research, 2014. 
HATTULA, J.D.; SCHMITZ, C.; SCHMIDT, M.; REINECKE, S. Is more always better? An investigation into the relationship between marketing influence and managers' market intelligence dissemination. International Journal of Research in Marketing. v.32, n.2, 2015.

HELM, R.; KRINER, S.; SCHMALFUSS, M. Conceptualization and Integration of Marketing Intelligence: The Case of an Industrial Manufacturer. Journal Business-to-Business Marketing, v.21, p. 237-255, 2014.

HSU, C.C.; SANDFORD, B. The Delphi Technique: Making Sense of Consensus. Practical Assessment, Research \& Evaluation, v.12, n.10, 2007.

JAHARUDDIN, N.S., MANSOR, Z.D.; YAAKOB, S. Supply Chain Intelligence Practices among Small Medium Enterprises in Malaysia. JSSH-Pertanika Journal of Social Sciences \& Humanities, v.24, p.223-238, 2016.

JANISSEK-MUNIZ, R. Fatores Críticos em Projetos de Inteligência Estratégica Antecipativa e Coletiva. Revista Inteligência Competitiva, v.6, n.2, p.147-180, 2016.

KANWAL, S.; SINGH, G.; SAMALIA, H.V. The Role of Organizational Culture and ProcessStructure in Marketing Intelligence. Journal of Cases on Information Technology, v.19, n.1, p.60-78, 2017.

KLAKURKA, J.A.C.; IRWIN, B. The Nature and Extent of Foresight-Infused Strategy: A Canadian Organizational Assessment. Proceedings of the Conference on European Management Leadership and Governance, p.133-139, 2016.

KOBUS, J.; WESTNER, M. Ranking-type Delphi studies in IS research. IADIS International Conference on Information Systems, Algarve, Portugal, 2016.

KONONIUK, A.; SACIO-SZYMANSKA, A. Assessing the maturity level of foresight in Polish companies-a regional perspective. European Journal of Futures Research, v.3, n.1, 2015.

KORTE, R.F.; CHERMACK, T.J. Changing organizational culture with scenario planning. Futures, v.39, 2007.

LAM, C. A importância de ter uma cultura organizacional no negócio. Revista Exame. São Paulo, 2015.

LANDIS, J.R.; KOCH, G.G. The measurement of observer agreement for categorical data. Biometrics, 33, 1977.

LEE, Y-I.; TRIM, P.R.J. Placing the Japanese retail sector in context: issues for marketers in overseas companies. Business Strategy Series, v.9, n.5, p. 243-248, 2008.

LESCA, H. Veille stratégique: La méthode L.E.SCAnning ${ }^{\circledR}$. Editions EMS. 180p., 2003.

LESCA, H.; JANISSEK-MUNIZ, R. Inteligência Estratégica Antecipativa e Coletiva: Método L.E.SCAnning ${ }^{\circledR}$. 188p. Porto Alegre, 2015. 
LESCA, N.; CARON-FASAN, M-L.; LOZA AGUIRRE, E.; CHALUS-SAUVANNET, M.-C. Drivers and barriers to pre-adoption of strategic scanning information systems. Systèmes d'information \& Management, v.20, n.3, p.9-46, 2015.

LESCA, N.; CARON-FASAN, M-L. Strategic scanning project failure and abandonment factors. European Journal of Information Systems, v.17, n.4, p.371-386, 2008.

LESCA, H.; LESCA, N. Les signaux faibles et la veille anticipative pour les décideurs. Hermès, Paris, 2011.

LIES, Jan. Marketing Intelligence and Big Data: Digital Marketing Techniques on their Way to Becoming Social Engineering Techniques in Marketing. International Journal of Interactive Multimedia and Artificial Intelligence, v. 5, n.5, 2019.

LIM, D.; KLOBAS, J. Knowledge management in small enterprises. The Electronic Library, v.18, n.6, p.420-432, 2000.

LUDWIG, B. Predicting the Future: Have you considered using the Delphi Methodology?

Journal of Extension, v.35, n.5, 1997.

MARQUES, J. B. V.; FREITAS, D. Método Delphi: caracterização e potencialidades na pesquisa em Educação. Pro-Posições, v.29, n.2, 2018.

MARQUES, L. K. S.; VIDIGAL, F. Prosumers e redes sociais como fontes de informação mercadológica: uma análise sob a perspectiva da Inteligência competitiva em empresas brasileiras. TransInformação, v.30, n.1, p.1-14, 2018.

MASON, D. Tailoring scenario planning to the company culture. Strategy \& Leadership, v.31, n.2, p.25-28, 2003.

MELATI, C.; JANISSEK-MUNIZ, R. Cultura Organizacional como Impulsionadora dos Processos de Inteligência na Gestão Pública. Revista de Administração, Contabilidade e Economia, v.16, p.131-156, 2017.

MEUNIER-FITZHUGH, K.L.; PIERCY, N.F. Improving the relationship between sales and marketing. European Business Review, v. 22, n. 3 p. 287-305, 2010.

MULLER, J.P. The relationships between organizational culture and environmental scanning: A case study. Library Trends, v.43, n.2, p.170-205, 1994.

MURRAY, P.; CARTER, L. Improving marketing intelligence through learning systems and knowledge communities in not-for-profit workplaces. Journal Workplace Learning, v.17, n.7, p.421-435, 2005.

NAHM, A.Y.; RAO, S.S; SOLIS-GALVAN, L.E.; RAGU-NATHAN, T. S. The Q-Sort Method: Assessing Reliability and Construct Validity of Questionnaire Items at Pre-Testing Stage. Journal of Modern Applied Statistical Methods, v.1, n.1, 2002.

NASRI, W. Competitive intelligence in Tunisian companies. Journal of Enterprise Information Management, v. 24, n. 1, p. 53-67, 2011. 
NELKE, M.; HAKANSSON, C. Competitive Intelligence for Information Professionals. Elsevier, 2015.

NEMETH, B; DEW, N.; AUGIER, M. Understanding some pitfalls in the strategic foresight processes: The case of the Hungarian Ministry of Defense. Futures, v.101, p.92-102, 2018.

PARÉ, G.; CAMERON, A-F.; POBA-NZAOU, P.; TEMPLIER, M. A systematic assessment of rigor in information systems ranking-type Delphi studies. Information and Management, v.50, p.207-217, 2013.

PASSINI, J.M; JANISSEK-MUNIZ, R.; CAINELLI, A.S. Proposta de instrumento de avaliação de maturidade do processo de Inteligência nas organizações. XXI SIMPOI, 2018.

PELLISSIER, R.; KRUGER, J.P. A study of strategic intelligence as a strategic management tool in the long-term insurance industry in South Africa. European Business Review, v.23, n.6, p.609-631, 2011.

PRYOR, C.; HOLMES JR., R.M.; WEBB, J.W.; LIGUORI, E.W. Top Executive Goal Orientations' Effects on Environmental Scanning and Performance: differences between founders and nonfounders. Journal of Management, 2017.

RIOS, F.L.C.; STRAUSS, L.M.; JANISSEK-MUNIZ, R.; BRODBECK, A. F. Inteligência competitiva, empresarial, estratégica ou de negócios? 6 $^{\mathbf{0}}$ Congresso IFBAE, 2011.

RIOS, F.L.C.; JANISSEK-MUNIZ, R. Uma proposta de relação de requisitos funcionais para um software de apoio ao processo de Inteligência. Revista de Administração, $78^{\text {ed }}$, n.2, 2014.

ROBBINS, S. P.; JUDGE, T.A. Organizational Behavior. Prentice Hall, 15ed., 2012.

ROHRBECK, R.; GEMÜNDEN, H.G. Corporate foresight: its three roles in enhancing the innovation capacity of a firm. Technological Forecasting Social Change, v.78, n.2, 2011.

ROHRBECK, R.; KUM, M.E. Technological Forecasting \& Social Change. Technological Forecasting Social Change, v.129, p.105-116, 2018.

RUSSO, M. Fundamentos de Biblioteconomia e Ciência da Informação. Rio de Janeiro, 2010.

SALGUERO, G.C.; RESENDE Jr., P.C.; FERNÁNDEZ, I. A. Proposal of an assessment scale in competitive intelligence applied to the tourism sector. Journal Intelligence Studies in Business, v.7, n.1, p.38-47, 2017.

SARKER, S.; SARKER, S. Exploring Agility in Distributed Information Systems Development Teams. Information Systems Research, v.20, n.3, p.440-461, 2009.

SCHEIN, Edgar H. Organizational Culture and Leadership. San Francisco, Jossey-Bass, 3ed, 2004.

SEWDASS, N.; DU TOIT, A. Current state of competitive intelligence in South Africa. International Journal of Information Management, v.34, p.185-190, 2014. 
SEWDASS, N.; DU TOIT, A. Competitive intelligence in emerging economies: a comparative study. The Journal for Transdisciplinary Research in Southern Africa, v.11, n.1, 2015.

SINGH, B.; TANWAR, S. Competitive Intelligence and Indian Retail Industry. Pacific Business Review International, v. 11, n. 8, p. 146-153, 2019.

TRIM, P. R. J.; LEE, Y. I. Vertically integrated organisational marketing systems: a partnership approach for retailing organisations. Journal of Business \& Industrial Marketing, v.21, n.3, p.151-163, 2006.

VECCHIATO, R. Creating value through foresight: First mover advantages and strategic agility. Technological Forecasting \& Social Change, 2015.

VIDIGAL, F. Competitive intelligence: functional practices, goals and infrastructure of companies in Brazil. Transinformação, 2013.

VISHNEVSKIY, K.; KARASEV, O.; MEISSNER, D. Integrated roadmaps and corporate foresight as tools of innovation management: The case of Russian companies. Foresight, v.17, n.5, p.460-474, 2015.

VIVIERS, W.; SAAYMAN, A.; MULLER, M-L. Enhancing a competitive intelligence culture in South Africa. International Journal of Social Economics, v.32, n.7, p.576-589, 2005.

WARRICK, D.D.; MILLIMAN, J.F.; FERGUSON, J.M. Lessons learned from Zappos on what it takes to build high performance cultures. Organizational Dynamics, 2016.

WHAITAKA, P. Moderating Effect of Organizational Factors Between Competitive Intelligence Practices and Performance of Firms Listed on the Nairobi Securities Exchange. European Scientific Journal, v.12, n.22, p. 213-223, 2016.

WIENER, M. Open foresight: The influence of organizational context. Creative Innovation Management, v.27, p.56-68, 2018.

WRIGHT, S.; PICKTON, D.W., CALLOW, J. Competitive intelligence in UK firms: a typology. Marketing Intelligence \& Planning, v.20, n.6, p.349-360, 2002.

WRIGHT, J. T.; SILVA, A. T. B.; SPERS, R. G. Prospecção de cenários: uma abordagem plural para o futuro do Brasil em 2020. Revista Ibero-Americana de Estratégia, v.9, n.1, 2010.

$\mathrm{XU}, \mathrm{M}$; KAYE, R. The nature of strategic intelligence, current practice and solutions. In: Xu, M. Managing Strategic Intelligence. Information Science Reference. New York. p.36-54, 2007. 